\title{
Organic carbon dynamics and enzyme activities in agricultural soils amended with biogas slurry, liquid manure and sewage sludge
}

\author{
Britta Stumpe ${ }^{1 *}$, Steffen Werner $^{1}$, Robert Jung $^{1}$, Stefanie Heinze $^{2}$, Elisabeth Jüschke ${ }^{3}$, \\ Christian Strippel ${ }^{4}$, Bernd Marschner ${ }^{1}$ \\ ${ }^{1}$ Department Soil Science/Soil Ecology, Institute of Geography, Ruhr-University Bochum, Bochum, Germany; \\ *Corresponding Author: britta.stumpe@,rub.de \\ ${ }^{2}$ Department of Environmental Chemistry, University Kassel, Witzenhausen, Germany \\ ${ }^{3}$ Department of Biogeochemistry, Max Planck Institute, Jena, Germany \\ ${ }^{4}$ Institute of Chemistry, Ruhr-University Bochum, Bochum, Germany
}

Received 4 September 2011; revised 12 October 2011; accepted 30 October 2011

\section{ABSTRACT}

The application of organic soil amendments is a common practice for increasing soil fertility and soil organic carbon (SOC) content. In recent years, a new product from biogas production, biogas slurry is increasingly applied to agricultural soils, although little is known about its effects on soil properties. In this study, the influence of this new product in comparison with liquid manure and sewage sludge on the organic carbon dynamics and enzyme activities were investigated in two different agricultural soils in short-term incubation studies. As a control, biologically inert sand was also amended with these organic wastes. In sand, biogas slurry degraded to $10.4 \%$ within 14 days, while no differences were found between the degradability of liquid manure and sewage sludge with $6.6 \%$ and $5.4 \%$, respectively. However, although the degradability of biogas slurry was highest among the organic amendments, liquid manure application resulted in the highest respiration rates in the soil samples. This was likely due to the organic waste borne easily decomposable substrates which were most dominant in liquid manure. Organic waste applications were found to generally increase the activity of numerous enzymes but did not change the soil enzyme patterns. Thus, in general it was shown that the microbial population of the organic wastes will not become prominent when introduced with the manures to soils. Thus, an inoculation with organic waste borne microorganisms could likely be neglected when discussing the extent of organic carbon dynamics after organic waste application to agricultural soils.
Keywords: Biogas Slurry; Organic Wastes; Organic Carbon Dynamics; Enzyme Activity; Priming Effects

\section{INTRODUCTION}

The application of organic soil amendments has gained importance worldwide since it increases soil fertility [1-3] and at the same time can contribute to $\mathrm{C}$ sequestration and the reduction of greenhouse gas emissions $[4,5]$.

With the advent of renewable energy production, agricultural biogas plants have become increasingly more attractive [6]. The biogas slurry remaining after fermentation is commonly used as organic fertilizer in agricultural practice [7]. Yet, biogas slurry was found to be different from conventional organic fertilizers such as liquid manure or sewage sludge, since the $\mathrm{NH}_{4}^{+}$content as well as the $\mathrm{pH}$ increase during fermentation, while the organic matter content decreases [6]. However, little information is available regarding effects of biogas slurry application to agricultural soils on soil organic carbon dynamics or on soil microbial processes. Reference [7] discussed that elevated $\mathrm{NH}_{4}^{+}-\mathrm{N}$ concentration in digested effluents indicates its potential suitability as a readily available $\mathrm{N}$ source but it may also enhance the carbon mineralization in amended soils and thus possibly trigger greenhouse gas emissions. On the other hand, [4] reported that the organic carbon in biogas slurry is more stable compared to other composts and wastes.

Although organic fertilizer amendments will increase the soil organic carbon content, it is known that the addition of organic residues to soils can also induce priming effects resulting in an increased SOC mineralization $[8$, 9]. As reported by [10], the highest emission of $\mathrm{CO}_{2}$ from soils generally occurs immediately after slurry applica- 
tion. Moreover, the incorporation of organic substances into soils may not only accelerate SOC mineralization but also retard it $[9,11]$. These positive or negative "priming effects" could affect different SOC pools. However, [12] suggested that only the labile SOC pool is affected and not the stable one. Since the organic matter of organic wastes is less stable than soil organic matter, priming effects may disarrange the ratio between stable and less stable organic carbon in agricultural soils which would contribute to the depletion of the stable organic $\mathrm{C}$ pool over long-term. Reference [13] observed an enhanced basal soil respiration in organic waste (OW) amended agricultural soils which they discussed to be due to a preferred decomposition of the OW derived organic matter. Altogether, it is likely that priming effects through OW amendments will occur in agricultural soils. Still up to date, it is not possible to predict how a specific organic fertilizer will act in a certain soil. Especially the role of biogas slurry in the context of priming effects in soil remains unknown.

Reference [14] reported that changes in the SOC pool through OW amendments are due to stimulated soil microbial processes by providing easily available substrates and nutrients that enhance decomposition of the stable soil organic matter. Previous studies [15-17] found an enhanced basal respiration, different activity of the soil microbial biomass, stimulated enzyme activities as well as different responses to substrate induced respiration in organic waste amended soils. However, it is unclear how organic amendments act as microbial inoculum to the soil. It is also uncertain whether OW-borne microflora leaves a long-term imprint on the soil microbial communities. Thus, a characterization of the microbial activity in organic wastes as well as in organic waste amended soils is necessary to obtain a definite understanding of organic carbon dynamics through organic waste amend- ments.

Consequently, the objective of this study was to assess the influence of the different organic inputs liquid manure, sewage sludge and especially biogas slurry on the mineralization of organic carbon as well as on its dynamics in two different agricultural soils. In laboratory experiments, we determined the short-term organic carbon degradability and mineralization, priming effects, basal respiration rates, substrate-induced respiration as well as enzyme activities resulting from the addition of different organic wastes. Furthermore, pure sand as a mineral carrier was amended with theses organic wastes and used as a control for the studied processes.

\section{MATERIALS AND METHODS}

\subsection{Soil Samples/Substrate and Organic Wastes}

Topsoil samples $(0-30 \mathrm{~cm})$ were collected from two agricultural fields, air-dried and sieved $(<2 \mathrm{~mm})$. The soils were selected for their textural differences. Physical and chemical characteristics for soil and organic waste samples are given in Table 1 . The sandy soil $(\mathrm{H})$ originnates from an avocado orchard in Hamapil (Israel). Samples were collected from four replicate plots and mixed. The loamy soil samples (L) originate from a loess agricultural field in Bochum (Germany). Both agricultural soils have been fertilized with NPK. Additionally, washed and calcined quartz sand (Sigma-Aldrich, Seelze) was used as a carrier for experiments with pure organic wastes (OW).

Biogas slurry (bs) and cattle liquid manure (lm) were collected from a biogas plant and from a dairy farm in Bottrop (Germany), respectively. Municipal activated sewage sludge (ss) was sampled from a sewage treatment plant in Bochum (Germany). Immediately after collection, all organic waste samples were air-dried, sieved and

Table 1. Physical and chemical properties of soil samples and different organic wastes.

\begin{tabular}{|c|c|c|c|c|c|c|c|c|c|c|}
\hline & abbrevitation & $\mathrm{pH}^{\mathrm{a}}$ & $\mathrm{OC}^{\mathrm{b}}$ & $\mathrm{DOC}^{\mathrm{c}}$ & OC degradability ${ }^{\mathrm{d}}$ & $\mathrm{N}^{\mathrm{e}}$ & $\mathrm{N}-\mathrm{NH}_{4}^{+} /$total $^{\mathrm{f}}$ & $\mathrm{C} / \mathrm{N}$ & $\operatorname{sand}^{g}$ & clay $^{g}$ \\
\hline & & {$\left[\mathrm{CaCl}_{2}\right]$} & {$[\%]$} & {$\left[\mathrm{mg} \cdot \mathrm{g}^{-1}\right]$} & {$\left[\mathrm{mg} \mathrm{CO}_{2} \mathrm{~g} \cdot \mathrm{OC}^{-1}\right]$} & {$[\%]$} & & & \multicolumn{2}{|c|}{$[\%]$} \\
\hline \multicolumn{11}{|l|}{ soil amples } \\
\hline Lottental & $\mathrm{L}$ & 7.6 & 1.5 & 0.2 & 0.04 & 0.29 & 0.004 & 5.2 & 7.3 & 15.9 \\
\hline $\begin{array}{c}\text { Hamapil } \\
\text { organic wastes }\end{array}$ & $\mathrm{H}$ & 7.3 & 1.7 & 0.1 & 0.05 & 0.20 & 0.003 & 8.6 & 81.6 & 9.6 \\
\hline biogas slurry & bs & 9.4 & 23.2 & 25.6 & 0.42 & 3.11 & 0.129 & 7.5 & nd & nd \\
\hline liquid manure & $\operatorname{lm}$ & 7.8 & 37.1 & 34.0 & 0.27 & 4.09 & 0.063 & 9.1 & nd & nd \\
\hline sewadge sludge & ss & 7.9 & 23.9 & 9.1 & 0.28 & 3.40 & 0.030 & 7.0 & nd & nd \\
\hline
\end{tabular}

a potentiometrically in $0.01 \mathrm{M} \mathrm{CaCl}_{2}$ at a solution ratio of 1:2.5 (DIN 19684); ${ }^{\text {be }}$ total caron and nitrogen were measured with a ON analyzer EA 3000 (Hekatech, Wegberg, Gamany); ${ }^{\mathrm{C}}$ DOC extraction with a solid to water ratio of 1:10, DOC analysis with the Dimatec, Eseen Germany); ${ }^{\mathrm{d}}$ described in the method section; fextraction with a solid to water ratio of 1:10, DOC analysis with the Dinatoc 2000 (Dimatec, Eseen Germany); ${ }^{\mathrm{g}}$ gieving and sedimentation after Kn (DINI SO 11277 (1994) nach DIN 19683, sheet 1 and 2 (1973)). 
ground to $2 \mathrm{~mm}$. The characteristics of the organic wastes are also listed in Table 1.

\subsection{Experimental Design of the Incubation Studies}

Since [10] reported that the highest $\mathrm{CO}_{2}$ emission from soils generally occurs immediately after slurry application, short-term incubation experiments (14 d) were performed. To assess short-term effects of organic waste amendments, we mixed the three different organic wastes with both agricultural soils and used these mixtures for all further incubation studies. Non-amended soil samples were used as controls. As a control for the $\mathrm{C}$ dynamics in pure organic wastes, the organic wastes were mixed with quartz sand. The dosage of the applied organic wastes was selected with respect to the $\mathrm{N}$ content, as it is common in agricultural practice [6]. Thus, soil/sand samples were mixed with a conventionally applied equivalent of about $100 \mathrm{t} \mathrm{N} \cdot \mathrm{ha}^{-1}$ (dosage 1 ) as well as with a 10-times higher equivalent of about $1000 \mathrm{t} \mathrm{N} \cdot \mathrm{ha}^{-1}$ (dosage 10).

\subsubsection{Short-Term Organic Carbon Mineralization}

To measure the effects of organic waste amendments on the SOC degradability and SOC dynamics, soil and sand samples were mixed with the organic wastes, rewetted to $60 \%$ water holding capacity and then incubated for two weeks at $20^{\circ} \mathrm{C}$ in a multi-channel respirometer (Respicond-apparatus, Nordgren Innovations). As a control, unamended soil samples were also rewetted and incubated. The treatments were carried out in triplicates. The organic carbon mineralization was calculated by measuring the evolved $\mathrm{CO}_{2}$ which was trapped in $10 \mathrm{ml}$ of $0.1 \mathrm{M} \mathrm{KOH}$ solution placed inside the incubation vessels in the respirometer. The total amount of $\mathrm{CO}_{2}$ release was recorded hourly by detecting the changes in electrical conductivity of the $\mathrm{KOH}$ solution. More details are described in [18].

In soils with high $\mathrm{pH}$ the formation of carbonates can interfere with $\mathrm{CO}_{2}$ release. However, all samples showed $\mathrm{pH}$ between 7.3 and 7.6 even after addition of the alkaline biogas slurry so that no relevant carbonate precipitation had to be expected [19].

\subsubsection{Priming Effects}

After two weeks of incubation, priming effects were determined to characterize the stability of the remaining more recalcitrant OC. To achieve this, solutions with uniformly ${ }^{14} \mathrm{C}$-labelled glucose (Amersham Pharmacia Biotech, England) were prepared and added to the incubated samples. According to [20], all samples received $13.3 \mu \mathrm{g}$ substrate $\mathrm{C} \cdot \mathrm{g}^{-1}$ sample $\mathrm{C}$ with an activity of $8000 \mathrm{~Bq}$. As controls, another set of samples received deion- ised water only. Over the following two weeks, the $\mathrm{CO}_{2}$ production was recorded hourly, while every second day the amount of ${ }^{14} \mathrm{CO}_{2}$ trapped in the $\mathrm{KOH}$ solution was quantified using liquid scintillation counting (Beckmann LK 6000 TA). The amount of substrate derived $\mathrm{CO}_{2}-\mathrm{C}$ was calculated from the amount of ${ }^{14} \mathrm{CO}_{2}$-C. The amount of SOC mineralized in the glucose amended samples was obtained by subtracting the amount of glucose derived $\mathrm{CO}_{2}-\mathrm{C}$ from the total amount of evolved $\mathrm{CO}_{2}-\mathrm{C}$ produced during the time interval of two weeks as described detailed in $[19,20]$.

\subsection{Extracellular Enzyme Activity Assays}

Since soil microorganisms degrade SOC by excreting enzymes, the extracellular enzyme activity of all samples was analysed. To analyze the basal enzyme activities, samples were taken directly after the first two weeks of incubation. These samples were analyzed with regard to the activity of six enzymes involved in the degradation of organic nitrogen (L-leucine, tyrosine, and arginine aminopeptidase), organic phosphorus (acid phosphatase) and cellulose ( $\beta$-glucosidase, $\beta$-cellobiohydrolase).

4-Mehylumbelliferone (MUB)-linked substrates were used to quantify the activities of acid phosphatase (pho), $\beta$-glucosidase (gluco) and $\beta$-cellobiohydrolase (cello). The aminopeptidase activating substrates were linked with 7-amino-4-methyl coumarin (AMC) as fluorescence dye, following the method of [21].

Sample suspensions were prepared by solving $1 \mathrm{~g}$ of soil/sand-organic waste samples in $100 \mathrm{ml}$ sterile deionizer water and sonicated for $120 \mathrm{~s}$ at 50 joule. Afterwards, the suspensions were continuously stirred using a magnetic stir plate while $200 \mu \mathrm{l}$ aliquots were dispensed into each of a 96-well microplate. Since the fluorescence intensity of MUB and AMC is highly dependent on $\mathrm{pH}$, all enzyme assays were carried out under buffered conditions. Thus, depending on the final substrate concentration in the wells, the appropriate amount of sterile buffer was also added into each well. Finally, $50 \mu \mathrm{l}$ of $200 \mu \mathrm{l}$ MUB- or AMC-substrate solutions were added to each microplate well. Each microplate also included three replicates of a quench standard (sample + buffer + MUB/ AMC standard) and a substrate control (sterile water + buffer + MUB/AMC). The plates were covered and incubated in the dark at $30^{\circ} \mathrm{C}$ for $3 \mathrm{~h}$. Fluorescence was measured after 30,60,120, 180 min using a microplate reader (infinite 200, Tecan, Germany) with $365 \mathrm{~nm}$ excitation wavelength and emission at $450 \mathrm{~nm}$. After correcting for negative controls and quenching, activities were expressed in $\mathrm{nmol} \cdot \mathrm{h}^{-1} \cdot \mathrm{g}^{-1}$.

\subsection{Statistical Analysis}

A t-test for unpaired groups was used to compare means of soil respiration, priming effects and enzyme 
activities between the control and organic waste treated soils. If more than two data sets were tested for significant differences with more than one factor univariate ANOVA was executed. Additionally, correlation analyses were performed to determine relationships between sample parameters and enzyme activities. Statistical analyses were carried out using SPSS 18.0 (SPSS Inc., Chicago, IL).

\section{RESULTS AND DISCUSSION}

\subsection{Organic Carbon Dynamics of the Easily Available SOC}

Before glucose addition, organic waste (OW) application at dosage 1 showed mostly no significant effects on respiration rates (Table 2). As an exception, an increase in the $\mathrm{CO}_{2}$ release from the Hamapil soil samples oc- curred after liquid manure as well as sewage sludge application. However, the effects of the organic amendments were more pronounced at the tenfold application rate, the presentation and discussion of results will focus on this.

In general, before glucose addition all organic wastes in the sand matrix showed high respiration rates of 5.6 to $11.3 \mathrm{mg} \mathrm{CO}_{2} \mathrm{~g}^{-1} 14 \mathrm{~d}^{-1}$ (Table 2) and high mineralizetion rates of 5.4 to $10.2 \%$ (data not shown) during the 2-week incubation, in accordance with earlier findings $[4,22,23]$. While no differences were found between respiration and mineralization rates of liquid manure and sewage sludge, biogas slurry showed the highest rates by far (Table 2). Thus, the biogas slurry was most degradeable. Reference [4] also investigated biogas slurry mineralization rates in laboratory experiments. They also found high mineralization rates for the biogas slurry of

Table 2. Respiration from SOM and OW in sand, Lottental and Hamapil soil samples before and after glucose addition. Also shown is ${ }^{14} \mathrm{C}$-glucose mineralization.

\begin{tabular}{|c|c|c|c|c|c|}
\hline \multirow[b]{2}{*}{ substrate/soil matrix } & \multirow[b]{2}{*}{ organic waste } & \multirow[b]{2}{*}{ dosage } & \multirow{2}{*}{$\begin{array}{c}\text { before glucose additon } \\
\text { respiration } \\
{\left[\mathrm{mg} \cdot \mathrm{CO}_{2} \cdot \mathrm{g}^{-1} 14 \mathrm{~d}^{-1}\right]}\end{array}$} & \multicolumn{2}{|c|}{ after glucose additon } \\
\hline & & & & $\begin{array}{c}\text { respiration } \\
{\left[\mathrm{mg} \cdot \mathrm{CO}_{2} \cdot \mathrm{g}^{-1} 14 \mathrm{~d}^{-1}\right]}\end{array}$ & $\begin{array}{c}{ }^{14} \mathrm{C} \text {-glucose mineralization } \\
{\left[\% 14 \mathrm{~d}^{-1}\right]}\end{array}$ \\
\hline \multirow[t]{7}{*}{ sand } & control & & 0.3 & 0.3 & 0.8 \\
\hline & biogas slurry & & $1.2 \mathrm{~ns}$ & $0.5 \mathrm{~ns}$ & $43.7^{* * *}$ \\
\hline & liquid manure & dosage 1 & $1.0 \mathrm{~ns}$ & $0.8 \mathrm{~ns}$ & $30.5^{* * *}$ \\
\hline & sewage sludge & & $0.8 \mathrm{~ns}$ & $0.7 \mathrm{~ns}$ & $34.2^{* * *}$ \\
\hline & biogas slurry & & $11.3^{* * *}$ & $4.7^{* * *}$ & $47.9^{* * *}$ \\
\hline & liquid manure & dosage 10 & $5.6^{* * *}$ & $3.3^{* * *}$ & $48.1^{* * *}$ \\
\hline & liquid manure & & $8.5^{* * *}$ & $2.6^{* * *}$ & $44.8^{* * *}$ \\
\hline \multirow[t]{7}{*}{ Lottental } & control & & 11.0 & 3.2 & 40.5 \\
\hline & biogas slurry & & $12.5 \mathrm{~ns}$ & $3.8 \mathrm{~ns}$ & $39.3^{*}$ \\
\hline & liquid manure & dosage 1 & $13.1 \mathrm{~ns}$ & $3.4^{*}$ & $39.9 \mathrm{~ns}$ \\
\hline & sewage sludge & & $13.2 \mathrm{~ns}$ & $3.9 \mathrm{~ns}$ & $39.8 \mathrm{~ns}$ \\
\hline & biogas slurry & & $26.4^{* * *}$ & $5.5^{* * *}$ & $40.2 \mathrm{~ns}$ \\
\hline & liquid manure & dosage 10 & $31.4^{* * *}$ & $5.9^{* * *}$ & $41.6 \mathrm{~ns}$ \\
\hline & sewage sludge & & $26.4^{* * *}$ & $5.4^{* * *}$ & $40.4 \mathrm{~ns}$ \\
\hline \multirow[t]{7}{*}{ Hamapil } & control & & 16.2 & 3.4 & 41.5 \\
\hline & biogas slurry & & $17.5 \mathrm{~ns}$ & $3.1 \mathrm{~ns}$ & $41.2 \mathrm{~ns}$ \\
\hline & liquid manure & dosage 1 & $19.2^{*}$ & $4.0 \mathrm{~ns}$ & $41.7 \mathrm{~ns}$ \\
\hline & sewage sludge & & $19.4^{*}$ & $3.9 \mathrm{~ns}$ & $41.5 \mathrm{~ns}$ \\
\hline & biogas slurry & & $27.6^{* *}$ & $5.3^{*}$ & $45.5^{* * *}$ \\
\hline & liquid manure & dosage 10 & $33.6^{* * *}$ & $6.0^{* *}$ & $40.9 \mathrm{~ns}$ \\
\hline & sewage sludge & & $31.1^{* * *}$ & $4.5^{*}$ & $44.5^{* *}$ \\
\hline
\end{tabular}

\footnotetext{
${ }^{* * *} \mathrm{p} \leq 0.001 ;{ }^{* *} \mathrm{p} \leq 0.01 ;{ }^{*} \mathrm{p} \leq 0.05$, t-test between control and amended samples, ns indicated no significant differences.
} 
up to $15 \%$ in 39 days.

Reference [6] argued that these high biogas slurry mineralization rates occurred due to the high amount of easily decomposable substrates within the biogas slurry. However, since the dissolved organic carbon (DOC) contents within the OW used is highest for liquid manure (Table 1), the amount of easily soluble compounds seems not directly correlated with the OW mineralization. Similar to [24], biogas slurry differed from the other wastes since it had the highest $\mathrm{pH}$ and the highest $\mathrm{NH}_{4}+$ content (Table 1). As stated by [25] this can also enhance microbial activity

In the unamended control soil samples, the respiration rates were significantly lower for the Lottental sample (Table 2). This can be attributed to the higher silt and clay content of this soil (Table 1) which contribute to the stabilization of soil organic matter (SOM) [26-29].

Organic waste application to both soil samples at dosage 10 resulted in distinct increases in soil respiration rates compared to the unamended control soils (Table 2), which is in agreement with previous studies [30,31]. With regard to the high mineralization rates of the pure organic waste materials in sand, this was most probably due to a preferred decomposition of the less stable organic-waste derived organic matter. Similarly, [31] reported an increased microbial decomposition of organic matter in compost amended soils. They attributed this increase to an enhanced amount of easily degradable compounds such as amino sugars, carbohydrates etc. introduced through compost organic matter. Similarly, [32] demonstrated that especially a high percentage of soluble organic carbon in different organic wastes leads to an increase of $\mathrm{CO}_{2}$ production immediately after their addition to soil. This was confirmed through our experiments since the highest increase in soil respiration occurred immediately after organic waste application and especially through the application of liquid manure which had the highest DOC content (Table 1) among the organic wastes added.

To focus on the SOC loss through OW amendments, Figure 1 shows the percentage of $\mathrm{CO}_{2}$ evolved from the OW amendment from both soil samples, in comparison to the percentage of the $\mathrm{CO}_{2}$ evolved from the control soil and OW amended sand. Differences between the total $\mathrm{CO}_{2}$ evolution and the sum of $\mathrm{CO}_{2}$ produced by the control soils and the organic wastes in sand were described as unaccounted part of the $\mathrm{CO}_{2}$ evolution.

Figure 1 clearly shows that the total SOC loss in the OW amended soil samples cannot be explained by the high respiration rates from OW borne OC (Table 1), since the total $\mathrm{CO}_{2}$ evolution greatly surpassed the sum of $\mathrm{CO}_{2}$ produced by the control soil and by the corresponding $\mathrm{OW}$ in the sand matrix.

This so called unaccounted part of $\mathrm{CO}_{2}$ produced was most pronounced in the liquid manure amended soil samples with $35 \%$ to $47 \%$ of the total respiration. Since these differences are more or less consistent in both soils, this additional SOC loss is controlled by the soil proper-

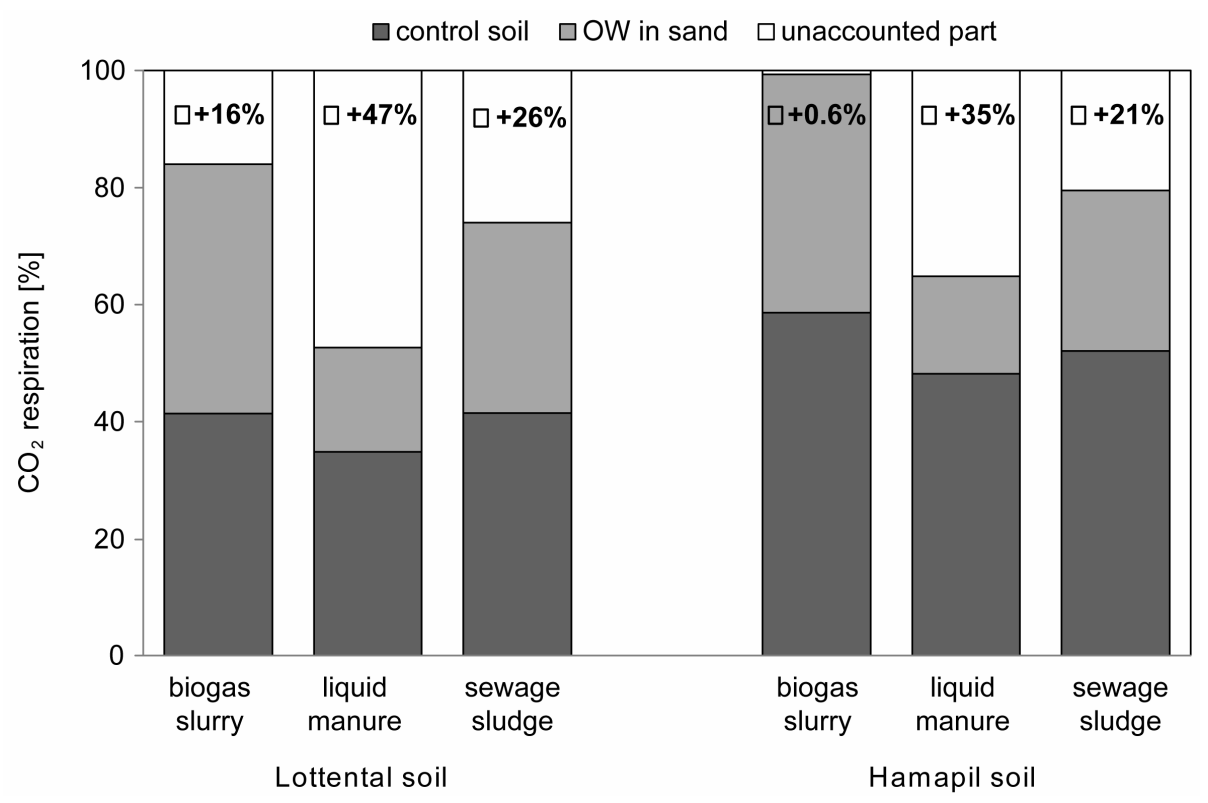

Figure 1. Relative contributions of soil organic matter and $\mathrm{OW}$ mineralisation to the overall $\mathrm{CO}_{2}$-release from the $\mathrm{OW}$ amended agricultural soils. Stacked bars represent $\mathrm{CO}_{2}$ release from the control soil samples (dark grey bars) and $\mathrm{CO}_{2}$ release from organic waste/sand samples (light grey bars). The unaccounted part of the released $\mathrm{CO}_{2}$ (white bars) is given percent of the total $\mathrm{CO}_{2}$-release. 
ties but by OW type. It can be assumed that either OW borne microorganisms or the OW substrate quality controls the SOC mineralization in the OW amended soils. To focus on these aspects, the enzyme activities as well as time dependent SOC mineralization were analyzed.

To visualize enzyme patterns in the different samples star plots were used (Figure 2). The enzyme patterns of the OW types differ from each other resulting in a distinct fingerprint. For example, in biogas slurry the enzyme activities follow the order phosphatase $>$ argenine $>$ tyrosine $>$ leucine $>\beta$-glucosidase $>$ cellohydrolase, while with liquid manure, the enzyme activities are in the order leucine $>$ argenine $>$ tyrosine $>$ phosphatase $>$ $\beta$-glucosidase $>$ cellohydrolase. The enzyme patterns in the control Hamapil and Lottental soil samples were quite similar but significantly different to the OW patterns. The OW amendments to both soil samples resulted in increased enzyme activities but did not shift the soil enzyme patterns. Thus, the OW borne microorganisms do not become prominent when introduced with OW to soil samples, most likely due to competition from the endemic population. Therefore, the high degradability of biogas slurry (Table 2), is not necessary related to a specific highly active microbial community, but rather to a high content of easily degradable compounds.

This is illustrated for the Hamapil soil in Figure 3, showing the time dependent SOC normalized soil respiration after organic waste addition. Within a few hours after OW application to the soil, initial respiration peaks occurred. However, liquid manure application resulted in the highest initial peak by far, indicating that it contains the highest amount of easily degradable substrates [8]. This shows that not the OW borne microorganisms but different organic substrate quality applied with the $\mathrm{OW}$ amendments is responsible for the increase in SOC mineralization. Similar to previous studies $[6,33]$, the labile OC pool seems to be smaller in the biogas slurry and in the sewage sludge than in liquid manure. In contrast to liquid manure, biogas slurry as well as sewage sludge were treated via digestion which depletes easily available substances [6]. Since priming effects are often explained through a co-metabolic SOC mineralization by stimulated microbial activity from easily available substrates [8], it can be concluded that the high amount of easily degradable substances in liquid manure caused positive SOC priming. This may explain why the highest unaccounted amount of the total OC loss in organic waste amended soils was found after the application of liquid manure. However, after an initial short but high respiration peak in all organic waste amended soil samples, a following long lasting $\mathrm{CO}_{2}$ peak was observed only in the samples mixed with liquid manure. Similar to [22], a second maximum in the $\mathrm{C}$ mineralization rate occurs most likely from the degradation of more resistant com-
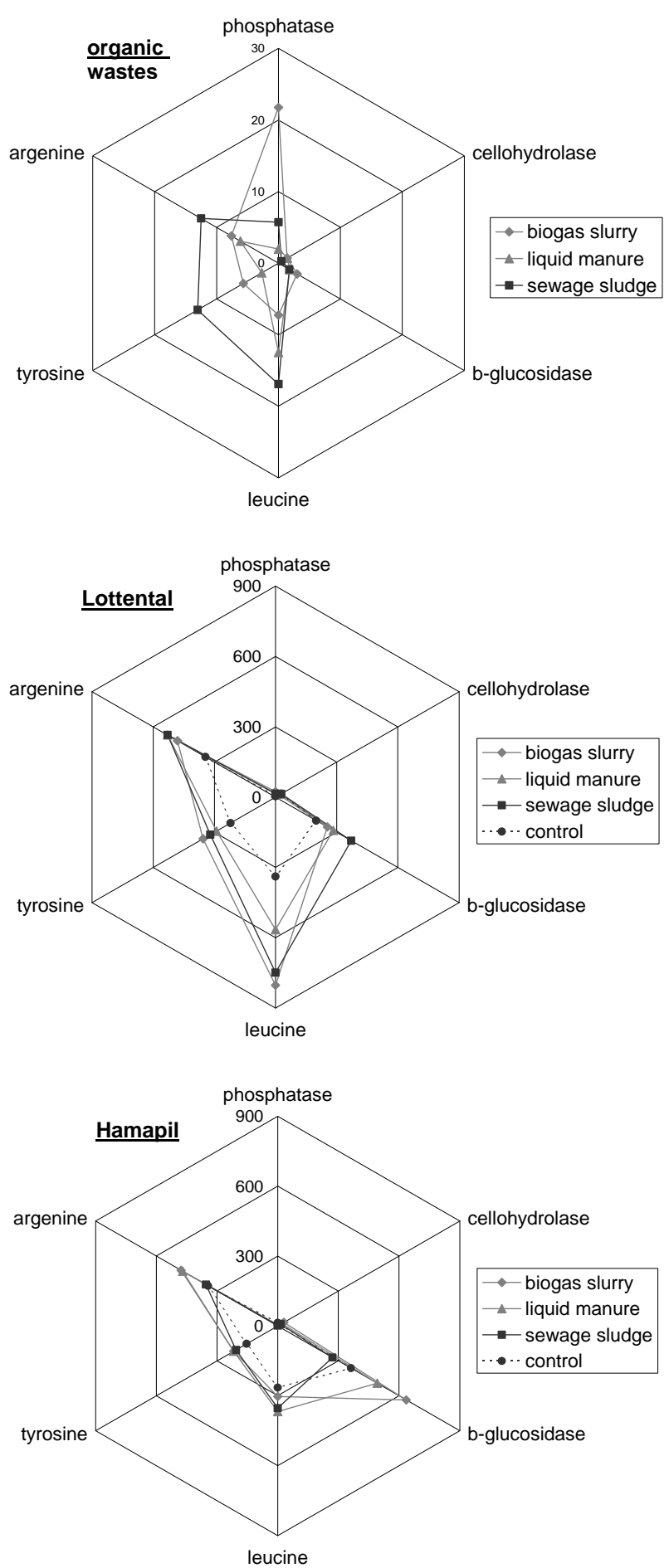

Figure 2. Spider web plots of the extracellular enzyme activity in $\mathrm{n} \mathrm{mol} \cdot \mathrm{g}^{-1} \mathrm{FB} \cdot \mathrm{h}^{-1}$ in the organic wastes (above) as well as in the control and organic waste amended Lottental (middle) and Hamapil (below) soil samples.

pounds. Since a second respiration peak in the biogas slurry and sewage sludge amended soils was absent, a second OC pool does not seem to exist or is not available during the incubation time in both wastes. 


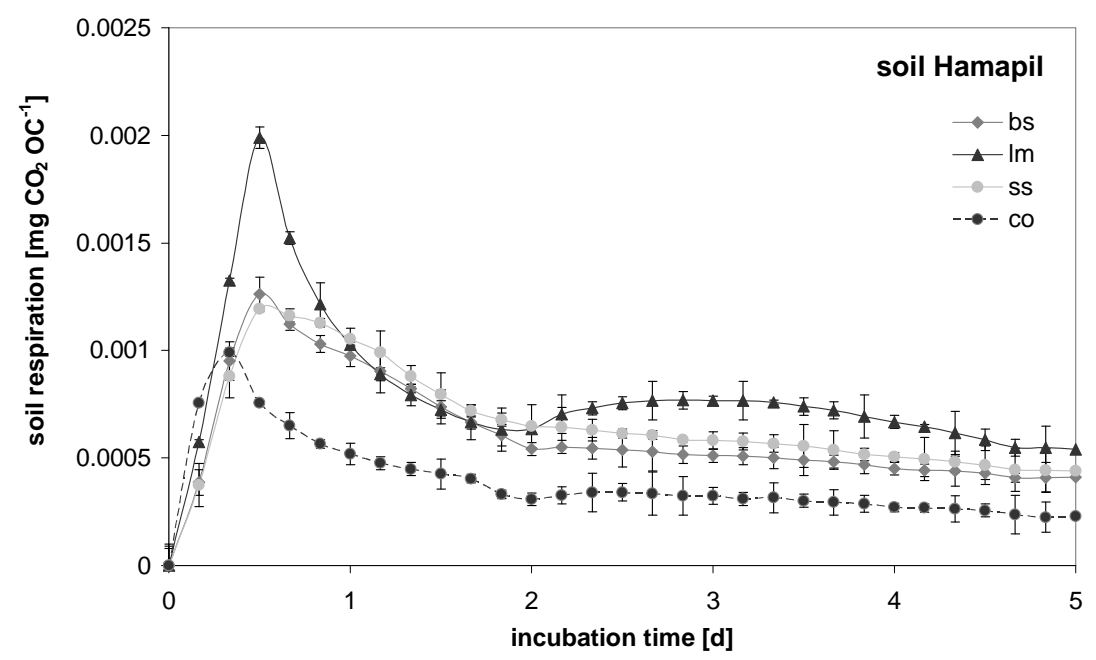

Figure 3. Soil respiration in the Hamapil soil mixed with biogas slurry (bs), liquid manure (lm), sewage sludge (ss) during the first five days of incubation.

\subsection{Organic Carbon Dynamics of the More Recalcitrant SOC}

Since the basal respiration was reached within two weeks of incubation in all samples (data not shown), it appears as if the available soil or organic waste borne OC was more or less depleted. To characterize and to compare the stability of the remaining more recalcitrant $\mathrm{OC}$ in the organic wastes, glucose as easily available substrate was added to all incubated samples in the control soils as well as in the organic waste amended soils. The results were described by respiration rates (Table 2), ${ }^{14} \mathrm{C}$-glucose mineralization as well as by calculated priming effects (Figure 4).

After glucose addition to the OW-sand mixture, the $\mathrm{CO}_{2}$ respiration was significantly lower than the respiration rate after $\mathrm{OW}$ application during the first two weeks of incubation, with values varying between 2.6 to $4.7 \mathrm{mg} \cdot \mathrm{g}^{-1} 14 \mathrm{~d}^{-1}$ (Table 2), . However biogas slurry still showed the highest respiration with $4.7 \mathrm{mg} \mathrm{CO}_{2} \mathrm{~g}^{-1} 14$ $\mathrm{d}^{-1}$. These findings are also reflected in the OC mineralization rates (data not shown).

Thus, after two incubation weeks remaining biogas slurry was still more degradable than liquid manure and sewage sludge.

After glucose addition, both control soil samples showed similar respiration rates of 3.2 to $3.4 \mathrm{mg} \cdot \mathrm{g}^{-1} 14$ $\mathrm{d}^{-1}$ and of 0.29 to $0.27 \% 14 \mathrm{~d}^{-1}$, respectively (Table 2). However, in the OW amended soils, glucose additions resulted in significantly higher respiration rates than in the control varying between 5.3 to $6.0 \mathrm{mg} \cdot \mathrm{g}^{-1} 14 \mathrm{~d}^{-1}$. Still, SOC respiration in the control and OW amended soil samples was up to five times lower than directly after OW application during the first two weeks of incubation.

Although the biogas slurry derived OC was also most degradable after two weeks of incubation (Table 2), soil samples amended with biogas slurry did not show the highest respiration rate. As observed during the first two weeks of incubation after OW application, liquid manure amendments to both soil samples resulted in the significantly highest respiration activities compared to biogas slurry and sewage sludge applications.

Since the ${ }^{14} \mathrm{C}$-glucose mineralization rates were quite similar in all samples (Table 2), this indicates that microbial activity in the samples was not limited by easily available substrates [19]. Again, this shows that OW application increased the labile organic matter in the samples.

To characterize effects of organic waste amendments on the stability of the more recalcitrant OC in the soil samples, we calculated the priming effects induced by the addition of glucose. The amount of OC which was released from OW samples and which was additionally released in the OW amended soil samples after substrate addition compared to the unamended control is shown in Figure 3. The addition of glucose accelerated the decomposition of OC in all samples as reflected in the positive priming effects of $39 \%$ to $158 \%$ (Figure 3 ). Within the OW-sand samples the priming effect was highest with biogas slurry. Priming effects in the liquid manure and sewage sludge samples reached $79 \%$ and $68 \%$, respectively, and were not significantly different.

In the soil samples, priming effects were generally lower in the Hamapil samples compared to the Lottental samples, while mostly no significant differences between the control soil and the OW amended samples were found. Biogas slurry amended Lottental soil sample was an exception in this context where the priming effect was lower than in the control soil. Previous studies [9,11] reported that the extent of priming depends on substrate 


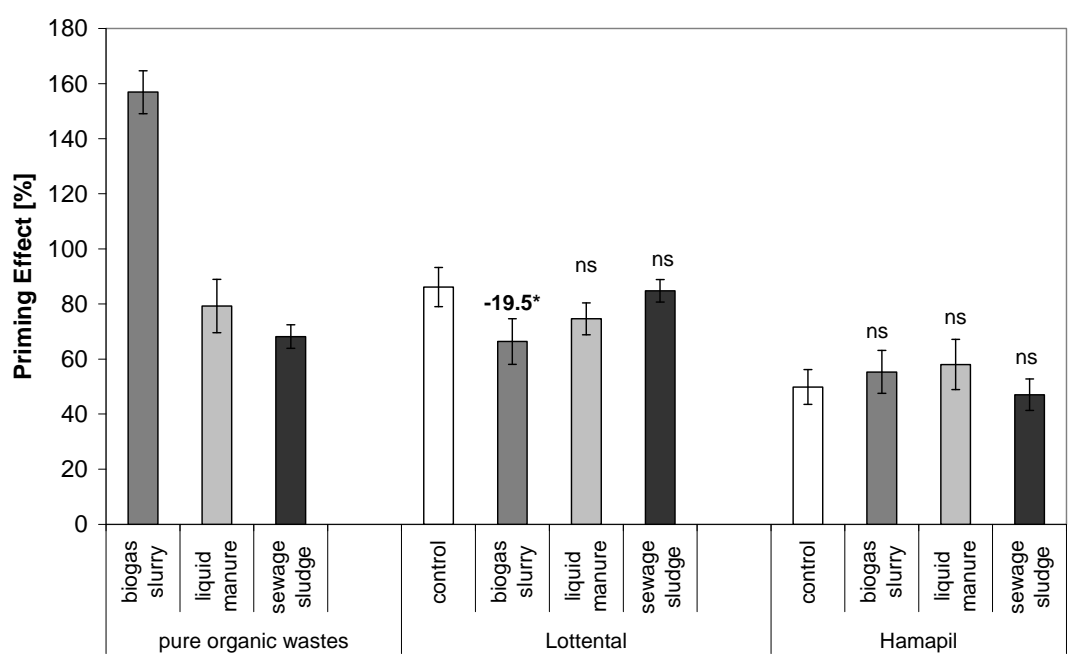

Figure 4. Priming effects (PE) through glucose addition to pure organic wastes (in sand) and to organic waste amended Lottental soil sample as well as to the Hamapil soil sample. (Error bars are representing the standard deviation, ${ }^{*} \mathrm{p} \leq 0.05$, t-test, ns indicated not significant differences of PE between treated and control soils).

type and substrate concentration. In organic waste amended soil samples glucose addition did not enhance the positive priming effects compared to the unamended control samples. This result indicates that these soils were already enriched with organic waste borne easily degradable compounds. Consequently, priming effects very likely occurred after addition of the amendments, thus explaining the unaccounted amounts of additional C-mineralization (Table 2).

\section{ENVIRONMENTAL IMPLICATION}

Short-term organic carbon dynamics in organic waste amended soils will most likely be influenced by the quality of the OC added with organic wastes. The inoculation with organic waste borne microorganisms only will contribute little to the C-dynamics in the soils.

Moreover, our results clearly show that although biogas slurry is different from other wastes with regard to $\mathrm{pH}, \mathrm{NH}_{4}^{+}$/total $\mathrm{N}$ content and organic matter stability, these properties did not influence the short-term organic carbon dynamics after mixing into soil samples Instead, soil organic carbon loss was highest after liquid manure addition, likely due to the high manure borne labile organic carbon content.

Since we performed short-term incubation studies, the amounts of total carbon loss cannot be transferred to field conditions. However, we showed that biogas slurry application has no greater impact on the soil organic carbon dynamics than other organic wastes such as liquid manure and sewage sludge. We applied organic wastes in two concentrations. While for the lower concentration the effects on carbon dynamics or on enzyme activity were not detectable, waste application at 10-times higher concentration resulted in significant effects. Although, it is likely that effects were overestimated, they obviously exist and were useful to identify differences in the effects of different organic wastes on SOC dynamics.

However, for an overall agronomic evaluation, it would be necessary to perform field trials to validate the results from this experimental study. Due to the increasing use of biogas slurry in agricultural practice during the last decade, this would be urgently needed.

\section{ACKNOWLEDGEMENTS}

We would like to acknowledge the DFG (Deutsche Forschungsgemeinschaft) for financial assistance.

\section{REFERENCES}

[1] Ayuso, M., Hernandez, T., Garcia, C. and Pascual, J.A. (1996) Biochemical and chemical structural characterization of different organic materials used as manures. Bioresource and Technology, 57, 201-207. doi:10.1016/0960-8524(96)00070-3

[2] Garland, J.L., Mackowiak, C.L. and Zabaloy, M.C. (2010) Organic waste amendment effects on soil microbial activity in a corn-rye rotation: Application of a new approach to community-level physiological profiling. Applied Soil Ecology, 44, 262-269. doi:10.1016/j.apsoil.2010.01.003

[3] Perez-Piqueres, A., Edel-Hermann, W., Alabouvette, C. and Steinberg, C. (2006) Response of soil microbial communities to compost amendments. Soil Biology and Biochemistry, 38, 460-470. doi:10.1016/j.soilbio.2005.05.025

[4] De Neve, S., Sleutel S. and Hofman, G. (2003) Carbon mineralization from composts and food industry wastes added to soil. Nutrient Cycling in Agroecosystems, 67, 


\section{3-20. doi:10.1023/A:1025113425069}

[5] Nendel, C. and Reuter, S. (2007) Soil biology and nitrogen dynamics of vineyard soils as affected by a mature biowaste compost application. Compost Science and Utilization, 15, 70-77.

[6] Terhoeven-Urselmans, T., Scheller, E., Raubuch, M., Ludwig, B. and Jörgensen, R. G., (2009) $\mathrm{CO}_{2}$ evolution and $\mathrm{N}$ mineralization after biogas slurry application in the field and its yield effects on spring barley. Applied Soil Ecology, 42, 297-302. doi:10.1016/j.apsoil.2009.05.012

[7] Senbayram, M., Chen, R. R., Muhling, K. H. and Dittert, K. (2009) Contribution of nitrification and denitrification to nitrous oxide emissions from soils after application of biogas waste and other fertilizers. Rapid Communication of Mass Spectrometry, 23, 2489-2498. doi: $10.1002 / \mathrm{rcm} .4067$

[8] Hamer, U. and Marschner, B. (2002) Priming effects of sugars, amino acids, organic acids and catechol on the mineralization of lignin and peat. Journal of Plant Nutrition and Soil Science, 165, 261-268.

doi:10.1002/1522-2624(200206)165:3<261::AID-JPLN2 61>3.0.CO;2-I

[9] Hamer, U. and Marschner B. (2005) Priming effects in different soil types induced by fructose, alanine, oxalic acid and catechol additions. Soil Biology and Biochemistry, 37, 445-454. doi:10.1016/j.soilbio.2004.07.037

[10] Fanguelro, D., Chadwick, D., Dixon, L. and Bol, R. (2007) Quantification of priming and $\mathrm{CO}_{2}$ emission sources following the application of different slurry particle size fractions to a grassland soil. Soil Biology and Biochemistry, 39, 2608-2620. doi:10.1016/j.soilbio.2007.05.012

[11] Kuzyakov, Y, Friedel, J.K. and Stahr, K. (2000) Review of mechanisms and quantification of priming effects. Soil Biology and Biochemistry, 32, 1485-1498. doi:10.1016/S0038-0717(00)00084-5

[12] Jenkinso, Ds. (1971) Studies on Decomposition of C14 labelled organic matter in Soil. Soil Science Society, 111, 64-70. doi:10.1097/00010694-197101000-00008

[13] Leifeld, J., Siebert, S. and Kogel-Knabner, I. (2002) Biological activity and organic matter mineralization of soils amended with biowaste composts. Journal of Plant $\mathrm{Nu}$ trition and Soil Science, 165, 151-159.

doi:10.1002/1522-2624(200204)165:2<151::AID-JPLN1 51>3.0.CO;2-T

[14] Hagedorn, F., Maurer, S., Blaser, P., Egli, P., Bucher, J. B. and Siegwolf, R. (2001) Carbon sequestration in forest soils: Effects of soil type, atmospheric $\mathrm{CO}_{2}$ enrichment, and $\mathrm{N}$ deposition. European Journal of Soil Science, 52, 619-628. doi:10.1046/j.1365-2389.2001.00412.x

[15] Emmerling, C., Liebner, C., Haubold-Rosar, M., Katzur, J. and Schroder, D. (2000) Impact of application of organic waste materials on microbial and enzyme activities of mine soils in the Lusatian coal mining region. Plant and Soil, 220, 129-138. doi:10.1023/A:1004784525209

[16] Pascual, J. A., Moreno, J. L., Hernandez, T. and Garcia, C. (2002) Persistence of immobilised and total urease and phosphatase activities in a soil amended with organic wastes. Bioresource Technology, 82, 73-78. doi:10.1016/S0960-8524(01)00127-4

[17] Kandeler, E., Mosier, A.R., Morgan, J.A., Milchunas, D.G., King, J.Y., Rudolph, S. and Tscherko, D. (2006) Response of soil microbial biomass and enzyme activities to the transient elevation of carbon dioxide in a semi-arid grassland. Soil Biology and Biochemistry, 38, 2448-2460. doi:10.1016/j.soilbio.2006.02.021

[18] Stumpe, B. and Marschner B. (2010) Organic waste effects on the behavior of $17 \beta$-estradiol, estrone, and $17 \beta$ ethinylestradiol in agricultural soils in long- and shortterm Setups. Journal of Environmental Quality, 39, $907-$ 916. doi: $10.2134 /$ jeq2009.0225

[19] Ohm, H. Broos, K. and Marschner, B. (2011) Priming effects after fructose and alanine additions in two copper and zinc contaminated Australian soils. Biology and Fertility of Soils, 47, 523-532. doi:10.1007/s00374-011-0566-0

[20] Ohm, H., Hamer, U. and Marschner, B. (2007) Priming effects in soil size fractions of a podzol Bs horizon after addition of fructose and alanine. Journal of Plant Nutrition and Soil Science, 170, 551-559. doi:10.1002/jpln.200625087

[21] Marx, M.C., Wood, M. and Jarvis, S.C. (2001) A microplate fluorimetric assay for the study of enzyme diversity in soils. Soil Biology and Biochemistry, 33, 16331640. doi:10.1016/S0038-0717(01)00079-7

[22] Bernal, M.P., Sanchez-Monedero M.A., Paredes, C. and Roig, A. (1998) Carbon mineralization from organic wastes at different composting stages during their incubation with soil. Agriculture, Ecosystems and Environment, 69, 175-189. doi:10.1016/S0167-8809(98)00106-6

[23] Sastre, I., Vicente, M.A. and Lobo, M.C. (1996) Influence of the application of sewage sludges on soil microbial activity. Bioresource Technology, 57, 19-23. doi:10.1016/0960-8524(96)00035-1

[24] Reinhold, G., Klimanek, E.M. and Breitschuh, G. (1991) The Influence of Biogas Production on Changes in the Carbon Dynamics of Slurry. Soil Science and Archology, 35, 129-137.

[25] Haider, K. (1996) Biochemie des bodens. Enke, Stuttgart.

[26] Hassink, J. (1997) The capacity of soils to preserve organic $\mathrm{C}$ and $\mathrm{N}$ by their association with clay and silt particles. Plant and Soil, 191, 77-87. doi:10.1023/A:1004213929699

[27] Marschner, B., Brodowski, S., Dreves, A., Gleixner, G., Gude, A., Grootes, P. M., Hamer, U., Heim, A., Jandl, G., Ji, R., Kaiser, K., Kalbitz, K., Kramer, C., Leinweber, P., Rethemeyer, J., Schaeffer, A., Schmidt, M.W.I., Schwark, L. and Weinberg, G.L.B. (2008) How relevant is recalcitrance for the stabilization of organic matter in soils? Journal of Plant Nutrition and Soil Science, 171, 91-110. doi:10.1002/jpln.200700049

[28] Six, J., Conant, R.T., Paul, E.A. and Paustian, K. (2002) Stabilization mechanisms of soil organic matter: Implications for C-saturation of soils. Plant and Soil, 241, 155176. doi:10.1023/A:1016125726789 
[29] Sollins, P., Homann, P. and Caldwell, B.A. (1996) Stabilization and destabilization of soil organic matter: Mechanisms and controls. Geoderma, 74, 65-105. doi:10.1016/S0016-7061(96)00036-5

[30] Bol, R., Moering J., Kuzyakov, Y. and Amelung, W. (2003) Quantification of priming and $\mathrm{CO}_{2}$ respiration sources following slurry-C incorporation into two grassland soils with different $\mathrm{C}$ content. Rapid Communication of Mass Spectrometry, 17, 2585-2590. doi:10.1002/rcm. 1184

[31] Jörgensen, R. G., Meyer, B., Roden, A.L. and Wittke, B. (1996) Microbial activity and biomass in mixture treat- ments of soil and biogenic municipal refuse compost. Biology and Fertility of Soils, 23, 43-49. doi:10.1007/BF00335817

[32] Marstorp, H. (1996) Influence of soluble carbohydrates, free amino acids, and protein content on the decomposition of Lolium multiflorum shoots. Biology and Fertility of Soils, 21, 257-263. doi:10.1007/BF00334901

[33] Moeller, K. (2009) Influence of different manuring systems with and without biogas digestion on soil organic matter and nitrogen inputs, flows and budgets in organic cropping systems. Nutrient Cycling in Agrosystems, 84, 179-202. doi:10.1007/s10705-008-9236-5 